\title{
Environmental communication on ecotourism development: a case study of Subak Sembung, Bali
}

\author{
Yeni Rosilawati, ${ }^{1, *}$ and Sri Khairunnisa Ariyati ${ }^{2}$ \\ ${ }^{1}$ Universitas Muhammadiyah Yogyakarta, Department of Communication Studies, 55183 \\ Yogyakarta, Indonesia \\ ${ }^{2}$ Universitas Muhammadiyah Yogyakarta, Department of International Relations, 55183 Yogyakarta, \\ Indonesia
}

\begin{abstract}
Ecotourism is a particular interest in tourism and often becomes the antithesis of mass tourism. Ecotourism development has several benefits: increased agricultural activities, product processing, Subak income, tourism awareness of Sapta Pesona and entrepreneurship, and recreational opportunities for the community. One of the ecotourism destinations in Bali is Subak Sembung. This paper analyzed the environmental communication conducted for the communities to promote Subak Sembung, Bali, as an ecotourism destination. This study utilized a qualitative research method with a case study approach. The findings were obtained from in-depth- interviews and documentation. Environmental communication itself is a plan and strategy through the communication process and media products to support policymaking, public participation, and its implementation in the environment. The results showed that environmental communication was carried out in Subak Sembung through socializing, counseling initiated by Subak Sembung, and collaborating with the local government. The communication environment also applied Tri Hita Karana (THK) values in Subak to sustain and promote Subak as ecotourism. The THK guides human behaviors in three critical relationships in their lives: the relationship between humans (pawongan), the environment (palemahan), and with God (parahyangan). Balance and harmony in these relationships are essential to achieve sustainability.
\end{abstract}

\section{Introduction}

Indonesia is an agrarian country with enormous natural resources in the agricultural sector, such as food crops, horticulture, plantations, forestry, fisheries, and the most extensive animal husbandry globally. The agricultural sector has played an essential role in contributing to Indonesia's economic development, which is also experienced by other developing countries [1].

\footnotetext{
*Corresponding author: yenirosilawati@umy.ac.id
} 
The agricultural sector provides food for the population, job and business opportunities for the community, especially in rural areas, produces raw materials for industrial management in rural and urban areas, becomes consumers of products made by industry (upstream and downstream industry), and a foreign exchange contributor for national income.

On the other hand, economic growth has been increasing in various countries (especially in the industrial and service sectors). In the last few decades, the agricultural sector has shown a declining contribution to national income in developing countries. The change in the economic contribution is part of economic transformation from the primary sector to the tertiary sector.

Subak Sembung is a rice paddy field in Denpasar that operates based on ecotourism. This area still possesses a significant amount of land that might be developed into an ecotourism destination. Subak Sembung is also already physically well-managed. A concrete road with a width of 2 meters was erected by the local community along the 1 kilometer rice paddy field sides. On this concrete road, they also built some traditional Balinese huts. While relaxing in these huts, tourists may take pictures of the rice paddy fields. In Subak Sembung, ecotourism is viewed as an effort to protect the environment. Subak Sembung's social, cultural, economic, and environmental potentials were underdeveloped, resulting in these potentials not being fully explored by the local community.

Subak Sembung obtains irrigation water from the Mambal Dam on the Ayung River. The government permanently built this bend and utilized 41 subaks in Tabanan Regency and Badung Regency. As with the subaks in Bali, farmers in the Subak Sembung area have irrigation and agricultural management based on traditional subak values. Subak conventional values that are still being implemented include water distribution, irrigation water allocation, planting schedule, and ritual activities in each planting season.

In setting the planting schedule and other activities, Subak Sembung pays attention to the days on the national calendar and are based on the Balinese Hindu calendar (1 month is 35 days). Cooperation activities and religious ceremonies at the subak, munduk, and individual farmer ritual levels are based on the stages of rice plant growth, from the beginning of receiving water to harvesting. This paper aims to analyze environmental communication to the community and the younger generation to educate Subak Sembung, Bali, as an ecotourism destination. Environmental communication is a plan and strategy to support the effectiveness of policymaking, public participation, and the environment through the communication process and media products.

Nurma Ali Ridwan [2] stated that local wisdom could be found in songs, proverbs, praises (sasanti), pearls of wisdom, slogans, and ancient books. For a long time, local wisdom has been practiced in society, resulting from trial and error from the diversity of empirical and non-empirical knowledge or aesthetic or intuitive.

According to Supsiloani [3], local wisdom includes two aspects: local wisdom that is real (tangible) and not real (intangible). Local real wisdom covers various factors such as value systems, procedures, and special rules enshrined in traditional scriptures or calendars.

Tri Hita Karana (THK) is a life philosophy that aims to achieve a balanced and consistent life attitude in which people believe in and devote themselves to God while also maintaining society's welfare [4]. THK, according to Pitana, teaches Balinese people to live in harmony with the environment while also preserving their culture [5].

THK includes a guide on how to behave toward one another (Pawongan), nature (Palemahan), and God Almighty (Parahyangan), as well as other resources. This guide enables people to achieve happiness in their lives [6]. THK is derived from the teachings of ancient Hinduism. THK covers a broad scope, including managing natural resources and water as in the Subak System in Bali [7]. 
Vipriyanti [8] added to reveal the pattern of public space management in the Hindu community in Bali and local wisdom in maintaining environmental aspects and reducing social cases, corruption, and high tax funding appear in individual behavior. This method can support the sustainability of life, especially on public resources owned together.

Another local wisdom that embodies the artifact system is the Tri Mandala. This concept divides a building or place into three categories. According to this concept, each house or building has three zones or layers: the sacred zone (utama mandala), which refers to the place of worship, the transitional zone (madya mandala) refers to human settlement buildings, and the third zone is the dirtiest or unholy site (nista mandala) such as animal shelter or storage and garbage collection [9].

From the above description, local wisdom is a cultural product of a system of ideas in values, ethics, customs, social systems in social and community organizations, and artifacts. Local wisdom also exists as tangible and intangible. Furthermore, local wisdom can be a social capital to develop itself and give extraordinary energy to cooperate in the community.

Environmental communication is the transmission of messages from a person or group of people to other people about environmental situations and conditions, both physical and social environments, whether private, group, public, or en masse. Environmental communication is a particular study of communication science that explicitly discusses the environment. The environment consists of the biotic environment, abiotic, and the social environment where humans have an essential role in ecosystems.

According to Alexander Flor, environmental communication is "the application of communication approaches, principles, strategies and techniques for the management and protection of the environment." [10]. Environmental communication as "a vehicle for understanding the environment and human relationship to the natural world, a symbolic medium used to build environmental awareness and negotiate public responses." Environmental communication is pragmatic in that "it informs, educates, persuades us and is constitutive, as it subtly creates meaning and directs consciousness to the wider world." [11].

According to Oepen, environmental communication is a plan and strategy through the communication process and media products to support policymaking, public participation, and implementation in the environment [12]. In a genuine sense, environmental communication is an integrated component of the policy.

Communication programs should not be a source- and media-centric only. There must be significant participation from the recipient of the community. Environmental communication programs absolutely must focus on empowering the audience, involving them, and not placing them in a passive position [13].

Tips or tactics that can be used in communication planning are known as communication strategies. According to Frianda, communication strategy is a roadmap for achieving goals through communication planning and management [14]. Communication strategy, according to Cangara, is the best combination of communication elements from the communicator, message, receiver channel, and influence designed to achieve optimal communication goals [15]. There are communication components in the communication strategy: (1) Communicators, (2) Communication Messages, (3) Communication Media, and (4) Target Audiences, are the four components of communication.

The communication process is supported by several elements [16]. The sender of the message, whether verbal or non-verbal, to the recipient or target audience. Sources are often referred to by communication observers and other scientists with other terms, including communicators, senders. A message is everything or a statement conveyed by the sender to the recipient where the communicator and the communicant have the same 
meaning. Statements can be in verbal or nonverbal forms that can be understood by the recipient.

Messages are interpreted with information. Channels and media are communication tools used to divert a message to others from a source or communicator. These media include newspapers, radio, films, television, and the internet. Communication channels of a more general nature can occur without tools or media, for example, in a group of people who do events at home, such as birthday celebrations, art events, and others [16].

Sustainable tourism includes ecotourism as a sub-component. The perceived potential of ecotourism as a viable tool for long-term development is the primary reason why developing countries are now embracing and incorporating it into their economic development and conservation strategies [17].

Ecotourism, also known as alternative tourism, entails visiting natural areas to learn, study, or participate in environmentally friendly activities, i.e., tourism based on the natural experience that helps local communities develop economically and socially. It focuses on learning about and experiencing nature, landscape, flora, fauna, and habitats, as well as cultural artifacts from the area.

Ecotourism is both an expansion and a refinement of the tourism-conservation relationship. It builds on the idea of using tourism to reinforce protection and vice versa, while also deepening the sustainability criteria. It first appeared in the late 1980s, at the start of the sustainable development movement. Early planners saw tourism as something that could and should be planned and managed in advance to help fund conservation and community development [17]. It was supposed to happen in parks and follow in the footsteps of the first national parks' tourism ideas. Beyond the parks, tourism aimed to benefit people in local communities, protect recreation opportunities and scenery, and meet more recent priorities such as biodiversity conservation and ecosystem integrity.

For a large portion of the business world, sustainable development has become a strategic issue. Since then, sustainable development has been an important part of the company's growth strategy [18]. Carbon offsets that allow developed countries to pay for pollution rights and avoid having to reduce their own emissions should not be counted towards contributions to the global climate fund, according to Khor and Ocampo, as well as several developing countries and many civil society organizations.

\section{Research Method}

A qualitative research method with a case study approach was used in this study. Qualitative research, according to Creswell, is a method of analyzing the meaning behind individuals or groups in social or human problems [19]. Adrijana Biba Starman defines qualitative research as an interpretive paradigm that emphasizes subjective experiences and their meanings for an individual [20]. To generate an in-depth, multi-faceted understanding of a complex issue in its real-life context, a qualitative research method with a case study approach is used [21]. A case study approach, according to Simons, is an in-depth examination of the complexity and uniqueness of a specific project, policy, institution, program, or system in a "real life" context from multiple perspectives [22]. This study conducted in-depth interviews and documentation using a qualitative research method and a case study approach. 


\section{Results and Discussion}

\subsection{Environmental Communication through Socialization and Counseling to Subak Farmers and Surrounding Communities}

The Subak Sembung organization consists of 200 farmers who actively participate and manage this rice field area which produces almost every year. At first, the Denpasar Environmental Agency (BLH) collaborated with the Center for Environmental Education (PPLH) of Udayana University (UnUd), Bali, to accompany them. Through assistance from the government, research institutions, and later NGOs, farmers in Subak Sembung are now not only producing rice, secondary crops, or other agricultural products. Still, they can manage their subak as a tourist spot. With assistance from the government, research institutions, and later NGOs, farmers in Subak Sembung can now produce rice, secondary crops, or other agricultural products. Also, they can manage their subak as a tourist spot.

Through socialization, training, and assistance to farmers to preserve the environment, environmental communication is carried out through socialization, saving rice fields, and preventing flooding. The rice fields in Peguyangan include a few green areas that are still maintained in the capital city of Bali Province. Farmers are also provided with organic farming, so that currently, farmers can only use organic fertilizers.

Together with Subak Sembung management, the government also raises agricultural activities, peken carik activities (markets held in rice fields), and religious rituals to have distinctive characteristics to increase public appreciation for subak. The revival of the traits possessed by Subak Sembung has resulted in increased public appreciation because of the emergence of a sense of belonging. The peken carik activity needs to be revived because it provides excellent benefits for farmers in Subak Sembung who trade and visitors who participate in these activities. Early Childhood Education (PAUD), Kindergartens, Elementary Schools, junior high schools will receive education in agriculture through peken carik activities, so it is crucial to develop Subak Sembung as a better tourist attraction in urban areas. Engineering tourist attractions following Subak rules is profitable for Subak Sembung members.

The ecotourism attraction of Subak Sembung in its engineering must be adapted to awig-awig, which aims to maintain all the original cultures and prevent tourism from exploiting agricultural activities. Engineering tourist attractions following Subak Sembung causes harmony between farming and tourism activities. Peken carik presents superior products of rice and organic vegetables that can be picked directly by visitors.

The counseling materials provided relate to innovations regarding the application of correct plant cultivation technology (seeds, seedlings, land management, spacing, fertilization, pest and disease control, and harvesting), packaging techniques, and product marketing. Another aspect discussed is related to Sapta Pesona to support the development of ecotourism.

Counseling and training in developing ecotourism are done in a participatory manner, where members of the farming community are actively involved in every activity. The goal is to ensure the sustainability of their farming and ecotourism development.

\subsection{Application of Tri Hita Karana Values in Subak Sembung Environmental Communication}

The agricultural culture in Subak Sembung that stands out is related to the distribution and allocation of irrigation water, setting a planting schedule, and a series of ritual activities at the subak and farmer levels. Individual, subak, and inter-subak ritual activities are carried out in several subaks in Bali. Ritual activities at Subak Sembung begin with a ceremony of 
receiving water (mendak toya or magpag toya), making seeds, transplanting/planting, growing rice plants to harvesting. The cultural aspect of subak has been developed long ago and since 2012 has been recognized by UNESCO as a world cultural heritage. Individual farmers perform ritual activities at a small temple located at the intake of the water channel.

The social interaction of the farmers in Subak Sembung is beneficial to preserve subak values and a harmonious and environmentally friendly subak environment. The ritual ceremonies in the Subak System are different from other irrigation systems found in regions in Indonesia. Tri Hita Karana values are applied to support sustainable ecotourism, as follows.

Table 1. Tri hita karana elemnts and its appllication.

\begin{tabular}{|c|c|}
\hline $\begin{array}{l}\text { Tri Hita Karana } \\
\text { Elements }\end{array}$ & Applications \\
\hline Parahyangan (God) & $\begin{array}{l}\text { 1. Subak has a holy site (temple) } \\
\text { 2. Subak must be kept sacred. } \\
\text { 3. Subak holds religious activities collectively. }\end{array}$ \\
\hline Pawongan & $\begin{array}{l}\text { 1. Cooperation activities for common interests such as } \\
\text { repairing dams, irrigation canals, farming roads, } \\
\text { subak halls, and others } \\
\text { 2. Conflicts between subak manners are related to } \\
\text { subak activities } \\
\text { 3. Conflict between subak manners and subak } \\
\text { management }\end{array}$ \\
\hline Palemahan & $\begin{array}{l}\text { 1. The irrigation canal is cleaned at the time of mendak } \\
\text { toya (ritual of searching holy water) before the next } \\
\text { rice crop season. } \\
\text { 2. Subak has huts. }\end{array}$ \\
\hline
\end{tabular}

The social value developed for ritual activities is togetherness. The farmers will bear all costs for activities. Environmental communication carried out by the Subak Sembung organization includes socialization to the community, educating the Subak and surrounding communities to maintain all the original cultures, and prevent tourism from exploiting agricultural activities. The counseling materials provided relate to innovations regarding the application of correct plant cultivation technology (seeds, seedlings, land management, spacing, fertilization, pest and disease control, and harvesting), packaging techniques, and product marketing. The community is actively involved in having a high sense of belonging to Subak to maintain and care for it.

Environmental communication is also done through the local values of wisdom Tri Hita Karana which is continuous to the community. The unapplied approach to local knowledge results in tiny community ownership of the programs being run. As for the embodiment of the values of Tri Hita Karana, which is done through subak is to maintain and maintain the holy place (temple) in subak, follow ceremonies and religious activities as the embodiment of parahyangan values, gotong royong as a form of pawongan values (interpersonal relationships) and maintain the sustainability of subak (Palemahan). Through local rules that are enforced (Pararem) then these three aspects are implemented with the principle of harmonious and balanced

An environmentally-friendly farming system focuses on local natural resources and reducing the chemicals to help farmers' lives and improve the environment to be better in the future. 
The local wisdom of Tri Hita Karana (THK) is used and applied in outreach to the community to preserve subak as an ecotourism area. Tri Hita Karana's (THK) concept maintains harmonious relationships with God, humans, and nature. The wisdom of the Balinese Hindu community refers to knowledge, experience, and a collection of local knowledge that is passed down from generation to generation.

The communication process is the first step and becomes the primary aspect of an environmental communication strategy, yet environmental communication is challenging.

It is necessary to design the right communication strategy to be well received by the communicant Environmental communication is a communication principle and technique for protecting and managing the environment to avoid ecological damage. This damage will impact society, both from the natural environment and human health [23]. For Balinese people, mountains are seen as the mother of agriculture, and agriculture is the mother of tourism. Agricultural culture in Balinese tourism is based on Hindu culture. Mountains, agriculture, and tourism have a close relationship and complement each other [24].

Environmental communication has several elements of communication. The first element is the source or communicator. According to [16], there can be more than one communicator, many people, or more than one person. In line with that, the communicator who conveys the message about preserving and socializing Subak as an ecotourism area is the Subak Management in collaboration with the Denpasar Environmental Agency (BLH) in partnership with the Center for Environmental Education (PPLH) Udayana University (Unud), Bali.

In Subak Sembung's environmental communication, socialization and education were carried out together with community leaders, and the government was involved. In the local Banjar regular community forum (sangkep), the community provides ideas and tries to overcome the problems they face, especially those related to subak problems and nature conservation.

Oepen [12] defined environmental communication as a plan and strategy through the communication process and media products to support policymaking, public participation, and implementation in the environment [12]. In Oepen's understanding, environmental communication is an integrated component in policy.

Environmental communication is also carried out through a continuous approach to the local wisdom values of Tri Hita Karana to the community. The approach to local knowledge that is not applied results in tiny community ownership of the implemented program. Tri Hita Karana through subak is maintaining and caring for sacred places (temples) in subak, participating in religious ceremonies and activities as an embodiment of parahyangan, cooperation as pawongan values (relationships), and preserving the subak (palemahan). Through enforced local rules (Pararem), these three aspects are carried out with harmonious and balanced principles.

\section{Conclusion}

Environmental communication is a plan and strategy to support the effectiveness of policymaking, public participation, and the environment through the communication process and media products. One of the ecotourism destinations in Bali is Subak Sembung. Subak Sembung is a rice paddy field in Denpasar that operates based on ecotourism. This area still possesses a significant amount of land that might be developed into an ecotourism destination. The environmental communication is organized by Subak, Farmer Organization collaborated with Denpasar Environmental Agency (BLH) in partnership with the Center for Environmental Education (PPLH) Udayana University (Unud), Bali. Through socialization, training, and assistance to farmers to preserve the environment, 
environmental communication is carried out through socialization, saving rice fields, and preventing flooding.

Environmental communication is also done through the local values of wisdom Tri Hita Karana which is continuous to the community. As for the embodiment of the values of Tri Hita Karana, which is done through subak is to maintain and maintain the holy place (temple) in subak, follow ceremonies and religious activities as the embodiment of parahyangan values, gotong royong as a form of pawongan values (interpersonal relationships) and maintain the sustainability of subak (Palemahan). Through local rules that are enforced (Pararem) then these three aspects are implemented with the principle of harmonious and balanced.

\section{References}

1. S. Thuvachote, Analysis of Agricultural Society System (2nd Ed), Prince of Songkhla University Thailand, 2007.

2. N. A. Ridwan, J. IBDA 5, 27 (2007).

3. Supsiloani, JUPIIS 5, (2013).

4. I. K. Wiana, Beragama Bukan Hanya Di Pura Agama Hindu Sebagai Tuntunan Hidup (Yayasan Dhrama Naradha, Denpasar, 1997).

5. I. Pitana, in Conrady R., Buck M. Trends Issues Glob. Tour. (Springer, Berlin, Heidelberg, 2010).

6. F. Bambang Siswanto, D. Zain., A. Thoyib., and Solimun, J. Manag. Soc. Sci. 4, 1 (2014).

7. N. Sutawan, Organisasi Dan Manajemen Subak Di Bali (Pustaka Bali, Denpasar, 2008).

8. N. U. Vipriyanti, in Gov. Shar. Resour. Connect. Local Exp. to Glob. Challenges, Twelfth Bienn. Conf. Int. Assoc. Study Commons (Cheltenham, England, 2008), pp. 1-7.

9. A. Suryono and L. Carissa, Pelestarian Kearifan Lokal Dalam Arsitektur Pada Resort Royal Pita Maha Di Ubud Bali (2015).

10. 1A. G. Flor, Environmental Communication: Principles, Approaches and Strategies of Communication Applied to Environmental Management (UP Open University, Philippines, 2004).

11. C. Robert, Environmental Communication And Public Sphere (SAGE Publications Inc, United States of America, 2010).

12. M. Oepen and W. Hamacher, Environmental Communication for Sustainable Development. (Deutsche Gesellschaft fur, Eschborn, 1999).

13. Yenrizal, Komunikasi Lingkungan Masyarakat Petani Pedesaan, Studi Etnoekologi Komunikasi Masyarakat Di Semende Darat Tengah, Muara Enim, Sumatera Selatan (Program Pascasarjana Unpad, Bandung, 2015).

14. V. Frianda, H. Hairunnisa, and G. Ghufron, EJournal Ilmu Komun. 6, 43 (2018).

15. H. Cangara, Perencanaan Dan Strategi Komunikasi (Raja Grafindo, Jakarta, 2013).

16. N. Suyomukti, Pengantar Ilmu Komunikasi (Ar-Ruzz Media, Jakarta, 2016).

17. T. Kiper, in Adv. Landsc. Archit. Murat Özyavuz (IntechOpen, London, 2013).

18. N. Haouari, A. Makan, and A. El Ghmari, Ann. Environ. Sci. Toxicol. 2, 080 (2017).

19. J. W. Creswell, Research Design, Qualitative, Quantitative and Mixed Methods Approaches (Sage Publications, Thousand Oaks, California USA, 2009).

20. A. B. Starman, J. Contemp. Educ. Stud. 1, 28 (2013). 
21. S. Crowe, K. Cresswell, A. Robertson, G. Huby, A. Avery, and A. Sheikh, BMC Med Res Methodol 11, 100 (2011).

22. H. Simons, Case Study Research in Practice (SAGE, London, 2009).

23. A. Flor and H. Cangara, Komunikasi Lingkungan: Penanganan Kasus-Kasus Lingkungan Melalui Strategi Komunikasi (Prenadamedia Group, Jakarta, 2018).

24. G. Suarja, P. P. Suardika, M. Drestha., D. A. Sauwibi., Y. Utama, and I. A. Eka Pertiwi Sari, Giri Amertha: Pengalaman Aqua Mambal Bersama Janma Dalam Mendorong Pelestarian Hulu DAS Ayung (Perkumpulan Janma, Denpasar, Bali, 2014). 